Dampak Transfer Pemerintah Pusat Terhadap Penurunan Ketimpangan Pendapatan Di Indonesia

\title{
DAMPAK TRANSFER PEMERINTAH PUSAT TERHADAP PENURUNAN KETIMPANGAN PENDAPATAN DI INDONESIA
}

\author{
Adhitya Wardhana ${ }^{1}$., Bambang Juanda ${ }^{1}$., Hermanto Siregar ${ }^{1}$ dan Kodrat Wibowo ${ }^{2}$ \\ ${ }^{1}$ Institut Pertanian Bogor., ${ }^{2}$ Universitas Padjadjaran \\ E-mail: adhitya.wardhana3@gmail.com
}

\begin{abstract}
ABSTRAK. Pemerintah Pusat berdasarkan UU No 33/2004 memberikan dana transfer kepada pemerintah daerah. Dana transfer pusat tersebut digunakan sebagai perimbangan keuangan daerah. Dana transfer yang diberikan pemerintah seperti Dana Alokasi Umum (DAU), Dana Alokasi Khusus (DAK) yang difungsikan sebagai stimulus fiskal bagi daerah. Dana transfer pusat diharapkan akan memberikan peningkatan pembangunan bagi daerah. Namun dana transfer pusat tersebut belum memberikan penurunan ketimpangan pendapatan antar daerah. Dana transfer pusat ini setidaknya dapat menutupi kebutuhan daerah. Ketimpangan pendapatan setiap daerah akan terjadi tetapi pemerintah akan memikirkan bagaimana ketimpangan pendapatan daerah dapat diturunkan. DAU merupakan salah satu hibah dari pemerintah pusat untuk menurunkan ketimpangan pendapatan antar daerah. Adanya aturan hold-harmless menjadikan pemberian DAU minimum sama dengan tahun lalu yang mengakibatkan fungsi DAU tidak berjalan. Fungsi DAU yaitu daerah yang kapasitas fiskal rendah akan diberikan DAU relatif besar. Dengan diberlakukan hold harmless membuat fungsi DAU tidak terjadi. Aturan hold harmless sudah tidak digunakan lagi setelah tahun 2009. Dalam penelitian ini mencoba untuk melihat faktor-faktor yang mempengaruhi ketimpangan pendapatan di Indonesia melalui instrumen fiskal seperti DAU dan DAK. Periode penelitian tahun 2001-2010 menggunakan regresi panel data. Hasil yang estimasi yang didapat yaitu DAU, DAK, infrastruktur jalan, aturan hold harmless dan jumlah penduduk mempengaruhi signifikan terhadap ketimpangan pendapatan. Selain melihat hasil estimasi dari persamaan ketimpangan pendapatan, penelitian ini akan melihat perkembangan ketimpangan pendapatan provinsi di Indonesia dengan menggunakan indeks Williamson. Hasil yang didapat ketimpangan pada daerah miskin lebih merata dibandingkan daerah kaya. Penentuan daerah kaya dan daerah miskin menggunakan median PDRB perkapita.
\end{abstract}

Keyword : DAU, DAK, Ketimpangan Pendapatan, Hold Harmless

\section{ANALYSIS INCOME INEQUALITY AND INFLUENCES GOVERNMENT TRANSFER TO DECREASED IN INCOME INEQUALITY IN INDONESIA}

\begin{abstract}
ABSTRACK. The Central Government is based on Law No 33/2004 provides the Government transfer to local government. Central government transfer used equalization local government financial. Government transfer such as general purpose grant (DAU) and special purpose grant (DAK). general purpose grant (DAU) and special purpose grant (DAK) which functioned fiscal stimulus for local government. Government transfers is expected to provide increased development of the region. However the government transfers provide a reduction in inequality of income between region. The government transfer is least to cover the needs of the region. General purpose grant (DAU) is one the grants from the central government to lower income inequality inter regional. Hold harmless rule to take into account the magnitude of general purpose grant (DAU) does not make the decline in inequality. This study looked determined factors inequality in Indonesian 2001-2010. After the rule hold harmless has eliminated 2008 showed estimation from general purpose grant (DAU), special purpose grant (DAK) significantly affected the decreasing inequality of income. This research will look at the development of the provinces income inequality by using Williamson index. The result of inequality on the poor region more prevalent than the rich region. The determination of the rich and poor region of using the median of GDP per capita.
\end{abstract}

Keyword : General Purpose Grant (DAU), Special Purpose Grant (DAK), Inequality and hold harmless 


\section{PENDAHULUAN}

Era desentralisasi fiskal, pemerintah daerah diberikan kewenangan dan keluasaan untuk mengelola sumber daya daerahnya. Kewenangan pemerintah daerah tersebut agar daerah lebih mandiri dalam mengelola keuangannya untuk meningkatkan pembangunan daerah. Pada era desentralisasi ini, pemerintah pusat memberikan dana transfer kepada pemerintah daerah. Dana transfer pusat digunakan untuk menstimulus fiskal untuk daerah dalam meningkatkan pembangunannya. Dana transfer pusat yang berfungsi sebagai penyeimbangan keuangan antar daerah dan peningkatan pembangunan melalui Dana Alokasi Umum (DAU dan Dana Alokasi Khusus (DAK).

Dana Alokasi Umum merupakan dana yang berbentuk hibah baik penggunaan dan pengelolaannya diserahkan kepada pemerintah daerah. Dengan transfer pusat seperti DAU diharapkan daerah lebih siap mengimplementasikan otonomi daerah. Selain itu daerah diharapkan sanggup untuk mengalokasi sumber dana tersebut terhadap sektor-sektor yang berpotensi untuk mendorong peningkatan investasi daerah dan berdampak terhadap peningkatan pelayanan publik. Begitu juga terhadap dana perimbangan lainnya seperti Dana Alokasi Khusus (DAK), yang diberikan kepada daerah dalam membiayai kebutuhan khusus yang menjadi prioritas nasional. Pemberian DAK berdasarkan bidang yang dijadikan prioritas nasional seperti bidang pendidikan, kesehatan, infrastruktur dll. Pemberian dana transfer tersebut diharapkan menurunkan ketimpangan pendapatan antar daerah. Namun kondisi yang terjadi, ketimpangan semakin besar dalam setiap tahunnya. Terlihat pada pada gambar ini dengan menggunakan box plot PDRB perkapita, setiap tahunnya ketimpangan mengalami peningkatan. PDRB perkapita provinsi DKI, Riau dan Kalimantan Timur memperlihatkan jarak kesenjangan yang cukup besar untuk provinsi lainnya. Kemudian dengan adanya aturan hold harmless, mengatur pemberian DAU tidak lebih kecil pada tahun sebelumnya. Fungsi DAU yaitu bagi daerah yang kapasitas fiskalnya rendah akan diberikan DAU yang relatif besar. Aturan hold harmless diberlakukan membuat daerah kaya seperti DKI, Riau dan Kalimantan Timur tetap diberikan DAU yang lebih besar padahal kapasitas fiskalnya sudah relatif besar dibandingkan daerah miskin. Diberlakukan hold harmless akan memperbesar ketimpangan pendapatan antar daerah.

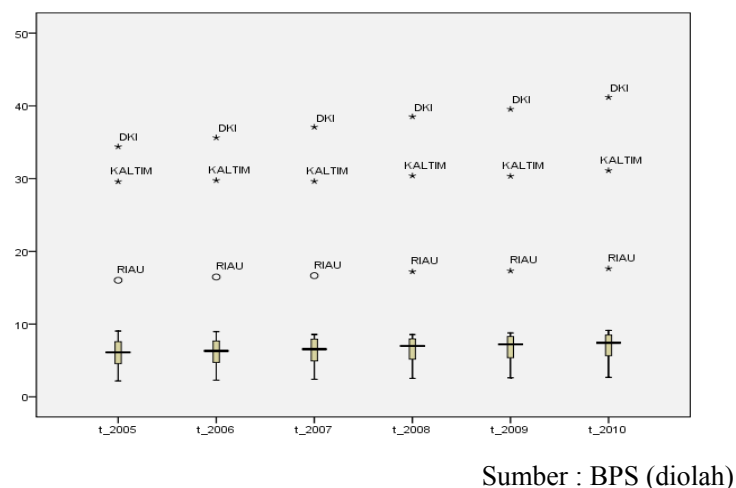

Gambar 1. Box Plot PDRB Perkapita Provinsi di Indonesia tahun 2005-2010

Ketimpangan antar daerah akan terus terjadi bahkan meningkat apabila tidak adanya implikasi atau kebijakan dari pemerintah dalam menurunkan ketimpangan tersebut, baik dari sisi fiskal maupun distribusi pendapatan. Menurut Nazara (2010) disparitas antar daerah adalah masalah struktural di perekonomian Indonesia. Dimana selama empat dekade pembangunan ekonomi tidak terjadi perubahan yang berarti dalam distribusi pendapatan antar daerah. Hal tersebut terjadi bersamaan dengan peningkatan pendapatan nasional dan pendapatan perkapita dalam kerangka proses akumulasi, alokasi dan transisi demografi.

Upaya pemerintah pusat dalam bentuk kebijakan untuk mengurangi ketimpangan dengan memberikan dana transfer. Dana tersebut harus dapat dimanfaatkan secara maksimaldanterarahsesuaidengankebutuhan daerah. Perlunya melihat kondisi pemberian transfer pusat kepada daerah apakah sudah dapat mengurangi ketimpangan atau tidak. Berdasarkan penjelasan diatas maka dapat diambil rumusan masalah penelitian sebagai berikut: 1) Bagaimana pengaruh DAU, DAK, kararistik daerah, diberlakukan hold harmless, infrastruktur jalan dan jumlah populasi terhadap ketimpangan pendapatan 
di Indonesia. 2) Sejauhmana perkembangan ketimpangan pendapatan di Indonesia. 3) Variabel mana yang paling mempengaruhi ketimpangan pendapatan di Indonesia.

\section{METODE}

Metode yang digunakan dalam menjawab rumusan masalah satu dan tiga menggunakan regresi panel data dengan periode tahun 2001-2010. Untuk karakteristik daerah dibuat sebagai dummy daerah kaya sama dengan satu. Variabel hold harmless dalam penelitian dibuat sebagai variabel dummy yang sebelum tahun 2009 diberikan nilai satu. Data yang digunakaan adalah data 32 provinsi di Indonesia. Sumber data didapat dari Badan Pusat Statistik (BPS). Penentuan Persamaaan ketimpangan pendapatan dapat dilihat sebagai berikut :

IW=f (dau, karakteristik daerah, dau daerah kaya, dak infrastruktur jalan, aturan hold harmless, infrastruktur jalan, jumlah penduduk )

Model yang akan digunakan yaitu :

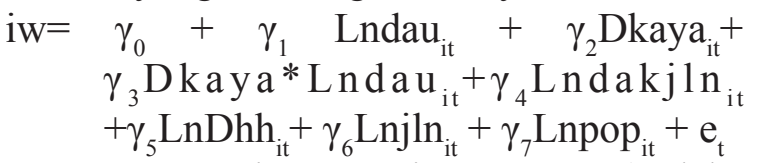

Keterangan: iw: Ketimpangan (Indeks Williamson); dau: Dana Alokasi Umum (juta); daujln: Dana Alokasi Khusus infratruktur jalan; pop: jumlah penduduk; Dkaya : Daerah kaya $=1, \mathrm{jln}$ : infrastruktur jalan; Dhh : aturan hold harmless sebelum tahun $2009=1$; $\mathrm{i}$ : Provinsi ke i, $\mathrm{t}$ : tahun ke $\mathrm{t}$

Untuk melihat perkembangan ketimpangan pendapatan antar provinsi di Indonesia dengan menggunakan Indeks Williamson. Indeks Williamson yang memperhitungkan nilai coefficient of variation (CV), semakin besar nilai Indeks Williamson semakin timpang. Adapun rumus dari Indeks Williamson ini :

$$
\mathrm{CV}_{\mathrm{w}}=\frac{\sqrt{\sum_{i}\left(Y_{i}-\bar{Y}\right)^{2} \cdot \frac{f_{i}}{n}}}{\bar{Y}}
$$

CVw: Indeks Ketimpangan Wilayah

fi: Jumlah Penduduk di Provinsi i

n: Jumlah Penduduk Nasional

Yi: Pendapatan Perkapita Provinsi

i: Rata-rata Pendapatan Perkapita untuk Seluruh Provinsi
Perhitungan indeks Williamson akan dilihat dari ketimpangan pendapatan seluruh provinsi, provinsi pendapatan tinggi atau provinsi kaya dan provinsi pendapatan rendah (provinsi miskin). Penentuan provinsi pendapatan tinggi (daerah kaya) dan provinsi pendapatan rendah (daerah miskin) didasarkan dari perhitungan nilai median dari PDRB perkapita. Data perkembangan ketimpangan pendapatan berdasarkan periode 2006-2010.

\section{HASIL DAN PEMBAHASAN}

Kondisi ketimpangan pendapatan yang setiap tahunnya mengalami kenaikan. Perlunya kebijakan fiskal yang dapat menurunkan ketimpangan tersebut. Selama ini kebijakan fiskal yang digunakan oleh pemerintah pusat berdasarkan UU No 33 Tahun 2004 dengan memberikan dana perimbangan kepada daerah untuk menyeimbangkan keuangan daerah. DAU dan DAK merupakan salah instrumen fiskal untuk menurunkan ketimpangan pendapatan antar daerah. Dari hasil estimasi ini terlihat nilai koefisien determinasi (R-squared) sebesar 0.926774, dimana model ketimpangan pendapatan hanya mampu menjelaskan $92.67 \%$ dan sisanya dijelaskan diluar model ketimpangan pendapatan. Sedangkan uji $\mathrm{F}$ terlihat dari P-(value) $\mathrm{F}$ sebesar 0.000, mengindikasikan variabel independen secara bersama-sama mempengaruhi signifikan terhadap ketimpangan pendapatan. Hasil estimasi ini menggunakan fixed effect model setelah dilakukan uji Hausman. Hasil dari uji Hausman Chi Square sebesar 19.3636 lebih besar dari Chi Tabel, maka persamaan ini lebih cocok menggunakan fixed effect model (Gujarati, 2009).

Uji multikolinearitas menggunakan coefficient correlation. Hasil dari pengujian dalam persamaan ketimpangan pendapatan tidak terdapat masalah multikolinearitas. Pada tabel dibawah tidak ada yang melebihi 0.8 (Gujarati, 2009) dan dapat disimpulkan tidak terjadi multikolinieritas. Untuk pengujian heterokedastisitas dan autokorelasi dalam persamaan ini sudah dikoreksi dengan robust (HAC) standar error. Oleh karena itu persamaan ketimpangan pendapatan sudah bebas dari masalah heterokedastisitas dan autokorelasi. 
Tabel 1. Faktor-Faktor yang Mempengaruhi Ketimpangan Pendapatan.

\begin{tabular}{lccccc}
\hline & Coefficient & Std. Error & t-ratio & $p$-value & \\
\hline Const & -0.318453 & 0.0196779 & -16.1833 & $<0.00001$ & $* * *$ \\
Lndau $_{\text {it }}$ & -0.000235404 & 0.000108115 & -2.1774 & 0.03029 & $* *$ \\
Dkaya $_{\text {it }}$ & 0.00658417 & 0.00251703 & 2.6159 & 0.00938 & $* * *$ \\
${\text { Dkaya } \operatorname{lndau}_{\text {it }}}_{\text {lndakjln }_{\text {it }}}$ & $7.13272 \mathrm{e}-05$ & $5.03261 \mathrm{e}-05$ & 1.4173 & 0.15751 & \\
dhh $_{\text {it }}$ & -0.000438652 & 0.000197429 & -2.2218 & 0.02709 & $* *$ \\
Lnjln $_{\text {it }}$ & 0.00888365 & 0.00239283 & 3.7126 & 0.00025 & $* * *$ \\
Lnpop $_{\text {it }}$ & -0.000817737 & 0.000339245 & -2.4105 & 0.01658 & $* *$ \\
\hline Mean dependent var & 0.023743 & 0.00123225 & 19.2680 & $<0.00001$ & $* * *$ \\
\hline Sum squared resid & 0.039441 & S.D. dependent var & & 0.024326 \\
R-squared & 0.013779 & S.E. of regression & & 0.007015 \\
F(38, 280) & 0.926774 & Adjusted R-squared & 0.916836 \\
Log-likelihood & 93.25731 & P-value(F) & & 0.000000 \\
Schwarz criterion & 1150.302 & Akaike criterion & & -2222.605 \\
Rho & -2075.762 & Hannan-Quinn & & -2163.961 \\
\hline
\end{tabular}

Keterangan: ***:Signifikan 1\%,**: Signifikan 5\%, * Signifikan 10\%

Sumber : hasil olahan data

Berdasarkan tabel 1, DAU, daerah kaya, dummy hold harmless, DAK infrastruktur jalan, infrastruktur jalan dan populasi masing-masing mempengaruhi signifikan terhadap ketimpangan pendapatan. Setiap kenaikan DAU satu persen akan menurunkan ketimpangan pendapatan sebesar $0.000235404 \%$. Hasil ini membuktikan dana transfer pusat berupa DAU dapat menurunkan ketimpangan pendapatan. DAU sebagai dana yang berbentuk hibah blok untuk menyeimbangkan keuangan daerah dan penurunan ketimpangan pendapatan.

Tabel2.HasilCoefficient Correlation PersamaanKetimpangan Pendapatan Provinsi di Indonesia

\begin{tabular}{lcccc}
\hline & Dau & dak_jln & Jln & Pop \\
\hline Dau & 1.0000 & 0.2520 & 0.0415 & 0.3758 \\
dak_jln & 0.2520 & 1.0000 & 0.0714 & -0.0735 \\
Jln & 0.0415 & 0.0714 & 1.0000 & 0.0698 \\
Pop & 0.3758 & -0.0735 & 0.0698 & 1.0000 \\
\hline
\end{tabular}

Sumber : hasil olahan data Keterangan: dau: Dana Alokasi Umum, dak_jln: Dana Alokasi Khusus bidang infrastruktur jalan, jln: infrastruktur jalan, pop: jumlah penduduk
Dalam hasil estimasi ini membuktikan DAU dapat menurunkan ketimpangan pendapatan antar daerah. Hasil ini sejalan dengan penelitian Martinez, Vaquez, Jorge, Boex dalam Juanda, Sidik, Qibthiyah (2013), menjelaskan ekualisasi kapasitas fiskal dan kebutuhan fiskal untuk mengukur celah fiskal banyak dilakukan di negara maju maupun negara berkembang. DAU merupakan bagian dari dana perimbangan yang digunakan untuk mengurangi ketimpangan horizontal antar daerah. DAU diberikan kepada daerah sangat tepat karena memperhitungkan kapasitas fiskal dan kebutuhan fiskal pemerintah daerah. Alokasi DAU berfungsi untuk mengurangi ketimpangan horizontal. Besaran DAU dapat mengurangi ketimpangan pendapatan dengan asumsi daerah benar-benar menggunakan alokasi DAU yang mayoritas untuk belanja modal bukan belanja rutin. dalam hasil estimasi ini memperlihatkan DAU sudah memberikan peranan atau kontribusi untuk menurunkan ketimpangan pendapatan. Hasil ini sesuai dengan penjelasan Simanjuntak R A dan Hidayanto D (2002), menyatakan bahwa DAU untuk menutupi daerah yang 
rendah terhadap PAD. Adanya DAU maka daerah yang memiliki PAD rendah akan teratasi dari adanya pemberian DAU. Berikut penelitian yang sesuai dengan hasil estimasi ini yaitu penelitian dari Swastyardi (2008). Dalam penelitiannya menjelaskan pemberian DAU digunakan untuk menutupi celah fiskal disetiap daerah agar keuangan daerah menjadi lebih seimbang dan dapat meningkatkan pelayanan publik. Alokasi DAU dilakukan untuk menyeimbangkan keuangan antar daerah dan ketimpangan horizontal. Dengan DAU diharapkan dapat menurunkan ketimpangan di daerah.

Dari hasil berbagai percobaan pada estimasi ketimpangan pendapatan, pengaruh DAK infrastruktur jalan merupakan variabel yang signifikan terhadap ketimpangan pendapatan selain DAK total, DAK bidang kesehatan dan pendidikan. DAK yang difungsikan untuk pemberian dana bidang infrastruktur yang menjadi prioritas nasional dan daerah mempengaruhi signfikan terhadap ketimpangan pendapatan. Setiap kenaikan satu persen dari DAK infrastruktur jalan akan menurunkan ketimpangan pendapatan sebesar $0.000438 \%$. Hasil ini sejalan dengan kajian akademis mekanisme penyusunan DAK untuk SPM. Dalam kajian ini dijelaskan DAK untuk mendorong pencapaian standar pelayanan minimum yang menjadi prioritas nasional. Pencapaian standar pelayanan minimum tersebut secara tidak langsung akan mempersiapkan sarana infrastruktur fisik maupun manusia menjadi lebih baik. Namun dari hasil penelitian ini, terlihat koefisien DAK infrastruktur jalan sangat kecil. Dapat diindikasikan, pengaruh DAK terhadap penurunan ketimpangan pendapatan antar daerah masih rendah. Besaran DAK belum mencukupi kebutuhan infrastruktur daerah, maka dalam menurunkan ketimpangan pendapatan relatif rendah. Selain itu dapat saja nilai DAK tidak sebesar nilai DAU, sehingga untuk mengatasi permasalahan infrastruktur daerah relatif berjalan lambat. Menurut penelitian Wibowo, Muljarijadi dan Rinaldi (2011), menyatakan tidak tercapainya dampak DAK yang diinginkan bukan berakibat dari kecilnya jumlah DAK melainkan kurang efisiennya alokasi DAK yang ada didaerah. Selain itu tidak efektifnya tata kelola dalam mengimplementasikan DAK. Perlunya mensinergiskan peranan DAK yang menjadi prioritas nasional dan juga kebutuhan pemerintah daerah di bidang infrastruktur dalam rencana kerja tahunan.

Variabel infrastruktur jalan mempengaruhi signifikan terhadap ketimpangan pendapatan. Setiap kenaikan satu persen dari infrastruktur jalan maka akan berdampak terhadap penurunan ketimpangan pendapatan sebesar $0.00082 \%$. Infrastruktur jalan sebagai dukungan aksesbilitas untuk melancarkan aktifitas perekonomian antar daerah. Infrastruktur jalan menjadi hal yang terpenting untuk menurunkan ketimpangan pendapatan dibandingkan jembatan dan irigasi. Dalam penelitian ini, hanya infrastruktur jalan yang dapat mempengaruhi signifikan terhadap ketimpangan pendapatan. Hasil ini sejalan dengan penelitian Sutarsono (2012), menjelaskan infrastruktur jalan dapat meningkatkan akses yang mendorong pertumbuhan ekonomi. Peningkatan infrastruktur jalan akan meningkatkan output dan ekonomi tumbuh. Penelitian Canning (1999), Canning dan Pedroni (2004), menjelaskan bahwa infrastruktur jalan harus memadai dan tidak berdampak langsung terhadap perekonomian. Perlunya akumulasi modal yang cukup besar untuk mendorong ekonomi tumbuh disetiap wilayah. Dengan mendorong pertumbuhan ekonomi di setiap wilayah setidaknya akan mengurangi ketimpangan. Hasil tersebut juga sesuai dengan penelitian Calderon dan Serven (2005), yang menjelaskan peningkatan kuantitas dan kualitas infrastruktur akan menurunkan ketimpangan pendapatan.

Variabel jumlah penduduk mempengaruhi signifikan terhadap ketimpangan pendapatan. Setiap kenaikan satu persen dari jumlah penduduk maka akan meningkatkan ketimpangan pendapatan sebesar $0.0237 \%$. Adanya penambahan jumlah penduduk membuat ketimpangan pendapatan semakin bertambah tinggi. Pesatnya jumlah penduduk usia non produktif menjadikan beban bagi penduduk usia kerja untuk membiayai jumlah penduduk non produktif. Jumlah penduduk usia non produktif di Indonesia 
mayoritas penduduk usia non berkerja atau penduduk usia dibawah 10 tahun. Kondisi pertambahan penduduk usia non produktif akan mengakibatkan ketimpangan pendapatan semakin bertambah buruk. Pertambahan penduduk dapat berdampak pada arus migrasi yang semakin besar. Dengan migrasi membuat penduduk mencari kesempatan kerja dan upah pada daerah yang maju. Dengan alasan tersebut akan menimbulkan ketimpangan antar daerah.

Daerah yang maju akan lebih banyak mendapatkan penduduk usia kerja yang produktif sehingga pertumbuhan ekonomi akan lebih cepat. Sedangkan daerah miskin pertumbuhan ekonomi akan berjalan lambat akibat penduduk usia kerja yang produktif lebih banyak di daerah maju. Terkadang penduduk tidak menyadari adanya lapangan kerja baru dan upah lebih tinggi akan menimbulkan ekonomi biaya tinggi. Timbulnya ekonomi biaya tinggi tersebut tetap tidak mencukupi kebutuhannya. Dampak besarnya arus migrasi ini perlahanlahan akan meningkatkan ketimpangan pendapatan. Hasil ini dijelaskan juga oleh Todaro (2010), menjelaskan adanya anggapan yang tidak realistis bahwa upah nyata didaerah maju lebih baik dan kesempatan kerja lebih terbuka. Namun kenyataannya daerah maju seperti perkotaan lebih banyak tingkat penganggurannya dibandingkan daerah pedesaan.

Dari hasil estimasi ini terlihat pada dengan tidak diberlakukannya aturan hold harmless ketimpangan semakin berkurang. Tidakberlakunyaholdharmless, memperkuat DAU untuk menurunkan ketimpangan ketimbang ketika berlakunyanya hold harmless.

Selanjutnya berdasarkan tabel 3 nilai ketimpangan pendapatan provinsi keseluruhan selama periode penelitian mengalami penurunan. Pada tahun 2006 nilai indeks Williamson sebesar 0.92. Kemudian tahun 2007-2008 cenderung tidak mengalami perubahan dengan nilai indeks Williamson sebesar 0.91. Penurunan ketimpangan pendapatan yang relatif kecil dari tahun 2006-2008, begitu juga dengan tahun 2009-2010 memiliki nilai konstan sebesar 0.89. Meskipun terjadi penurunan ketimpangan pendapatan, tetapi nilai ketimpangan provinsi keseluruhan hanya mengalami sedikit perubahan.

Kondisi yang sama pun terjadi ketimpangan pendapatan provinsi dengan pendapatan tinggi, bahkan dilihat dari nilai indeks ketimpangan pendapatan lebih besar dibandingkan ketimpangan provinsi total. Ketimpangan pendapatan yang besar di provinsi kaya (pendapatan tinggi) dapat diakibatkan dengan meningkatnya jumlah penduduk yang ada di provinsi kaya tersebut sehingga akan menimbulkan ketimpangan pendapatan, semakin tinggi jumlah penduduk tanpa dibarengi peningkatan pendapatan maka semakin rendah pendapatan yang didapat dari setiap individunya. Berbeda dengan ketimpangan pendapatan yang terjadi provinsi miskin, dalam setiap tahunnya mengalami penurunan ketimpangan pendapatan dan nilai indeks Williamson terendah dibandingkan dengan nilai indeks Williamson provinsi keseluruhan dan provinsi kaya. Hal ini diindikasikan dengan membandingkan jumlah penduduk yang ada di provinsi berpendapatan tinggi, dimana jumlah penduduk provinsi pendapatan rendah relatif lebih kecil dibandingkan provinsi kaya. Arus migrasi akan memberikan dampak terhadap ketimpangan pendapatan, sebagai contoh provinsi yang ada dipulau Jawa seperti Jawa Barat, DKI dan Jawa Timur akan lebih timpang dibandingkan dengan provinsi yang ada dibagian Indonesia Timur.

\section{Implikasi Kebijakan}

Berdasarkan hasil estimasi terdapat beberapa penemuan yang dapat dijadikan implikasi kebijakan, diantaranya :

a. Pemerintah pusat diharapkan mengevaluasi kembali untuk pemberian DAU kepada daerah dengan meninjau alokasi dasar, kebutuhan fiskal dan kapasitas fiskal daerah.

b. Pemerintah pusat diharapkan meninjau kembali Dana Alokasi Khusus terutama peninjauan kebutuhan daerah dari sisi 
Tabel 3. Nilai Indeks Williamson Provinsi, Provinsi Kaya dan Provinsi Miskin

\begin{tabular}{cccc}
\hline Tahun & $\begin{array}{c}\text { IW_ } \\
\text { CV }\end{array}$ & $\begin{array}{c}\text { IW_CV } \\
\text { (Rich) }\end{array}$ & $\begin{array}{c}\text { IW_CV } \\
\text { (Poor) }\end{array}$ \\
2006 & 0.92 & 0.92 & 0.57 \\
2007 & 0.91 & 0.92 & 0.56 \\
2008 & 0.91 & 0.91 & 0.55 \\
2009 & 0.89 & 0.90 & 0.53 \\
2010 & 0.89 & 0.90 & 0.52 \\
\hline
\end{tabular}

Sumber : Pengolahan Data

Keterangan: IW_Cv: Ketimpangan pendapatan provinsi, IW_Cv (Rich): Ketimpangan pendapatan provinsi Kaya, IW_CV (Poor): Ketimpangan pendapatan provinsi miskin.

infrastruktur yang dijadikan prioritas nasional. Pemerintah pusat diharapkan mendapatkan mekanisme yang terbaik dengan berbagai alternatif dalam menyusun DAK yang ditujukkan untuk pencapaian standar pelayanan minimum.

c. Pemerintah pusat diharapkan untuk memperbesar alokasi DAK sesuai dengan bidang pada dana transfer dan disesuaikan dengan kebutuhan daerah.

d. Kemudian pemerintah pusat dalam memberikan DAK kepada daerah diharapkan dapat mencapai standar pelayanan minimum daerah. Untuk mencapai standar pelayanan minimum tersebut, perhitungan DAK dapat dilakukan dengan berbagai alternatif baik untuk daerah tertentu maupun semua daerah.

e. Pemerintah pusat dalam melakukan perhitungan DAK diharapkan berdasarkan kriteria-kriteria yang relevan dan juga dilihat dari kelayakan daerah dalam mendapatkan DAK.

\section{SIMPULAN}

Variabel DAU dan DAK infrastruktur jalan berpengaruh signifikan terhadap ketimpang- an pendapatan. Variabel DAU dan DAK sebagai instrumen kebijakan fiskal dapat menurunkan ketimpangan pendapatan. Hal ini dilihat dari pengaruh DAU dan DAK terhadap ketimpangan pendapatan dengan nilai koefisien negatif. Dalam persamaan ini menjelaskan bahwa adanya aturan hold harmless membuat ketimpangan semakin besar. Dengan menghapuskan aturan hold harmless merupakan suatu yang tepat, karena dari hasil estimasi persamaan ketimpangan memiliki nilai positif. Artinya ketika masih diberlakukan hold harmless ketimpangan pendapatan semakin meningkat. Setelah tidak diberlakukan aturan hold harmless, memperkuat DAU dalam menurunkan ketimpangan pendapatan.

Variabel infrastruktur jalan mempengaruhi signifikan terhadap ketimpangan pendapatan. Peningkatan infrastruktur jalan diindikasikan dapat menurunkan ketimpangan pendapatan melalui aksesibilitas. Jumlah penduduk mempengaruhi signifikan terhadap ketimpangan pendapatan dengan korelasi negatif. Peningkatan jumlah penduduk non usia produktif membuat beban ketergantungan penduduk produktif semakin membesar. Beban ketergantungan tersebut jika tidak diatasi akan menambah ketimpangan pendaatan antar daerah.

\section{DAFTAR PUSTAKA}

Canning, D. (1999), "Infrastructure's Contribution to Aggregate Output", Policy ResearchWorking Paper Series 2246, The World Bank.

Calderón, C., Servén L 2005. “The effects of infrastructure development on growth and income distribution", World Bank Policy Research Working Paper 3643. World Bank, Washington, D.C.

Canning, Pedroni 2004, "The Effect of Infrastructure on Long Run Economic Growth", World Bank Policy Research Working Paper. World Bank, Washington D.C.

Gujarati, D N, 2009. Basic Econometrics $5^{\text {th }}$ Edition. McGraw-Hill.

Juanda, Sidik, Qibthiyyah, 2013, Kajian Akademik : Reformulasi DAU Untuk Memperkuat Peran Sebagai Equalization Grant, Tim Asistensi Kementerian Keuangan RI, Bidang Desentralisasi Fiskal, 2013

Kementrian Keuangan, 2013, DJPK Direktorat Dana Perimbangan, Pemyusunan Mekanismen Dana Alokasi Khusus untuk Pembiayaan Standar Pelayanan Minimum 
Nazara S. 2010. Pemerataan Antardaerah sebagai Tantangan Utama Transformasi Struktural Pembangunan Ekonomi Indonesia Masa Depan. Pidato Pengukuhan Guru Besar Tetap Bidang Ilmu Ekonomi. Universitas Indonesia.

Simanjuntak R A, Hidayanto D, 2002, "Dana Alokasi Umum di Masa Depan; Dana Alokasi Umum, Konsep, Hambatan, dan Prospek di Era Otonomi Daerah", LPEM-UI, Jakarta.

Sutarsono, 2012. "Hubungan Tata Kelola Pemerintahan, Infrastruktur dan Pertumbuhan Ekonomi di Indonesia", Thesis, IPB, 2012

Swastyardi D, 2008, "Regional Inequality Indonesia: Is the General Allocation
Fund likely to have an impact?", Graduate School of Development Studies, Institute of Social Studies, Netherland

Todaro M P, 2010, Economic Development, 11 th eds, Pearson Addision Wesley Boston

UU No. 33/2004 Tentang Hubungan

Keuangan antara Pusat dan Daerah, Kementerian Keuangan RI.

Wibowo, Muljarijadi, Rinaldi, 2011, "Allocation Mechanism Of Equalization Fund In Indonesia: Current Condition And Alternative Proposals Of Specific Grant In Sub National Level", Working Paper in Economic and Development Studies, 2011. 